\title{
Lojistik Hizmet Kalitesinin Müşteri Güvenine Etkisi ve Intermodal Taşıma Hizmetlerinde Bir Uygulama*
}

\author{
Oktay Güngör ${ }^{1}$ \\ Aynur Acer ${ }^{2}$
}

Öz

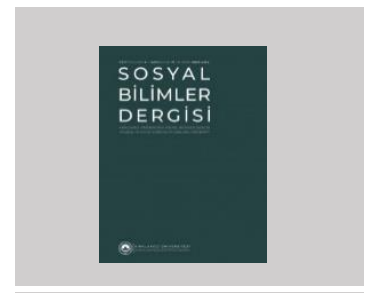

Makale Türü

Araştırma Makalesi

Başvuru Tarihi

22.11.2021

Kabul Tarihi

04.12.2021

$\mathrm{DOI}$

10.47140/kusbder.1027177

Günümüzde kullanımı yaygınlaşan taşıma türlerinden birisi de intermodal taşımacılıktır. Taşıma ünitesi değiştirilmeksizin iki ya da daha fazla taşıma türünün bir arada kullanıldığı intermodal taşımada yolculuğun kısa mesafeli olan başlangıç ve bitiş kısımlarından intermodal taşımacılık hizmetlerinden yararlanılmaktadır. Tek modlu taşımaya oranla taşıma maliyetlerinin daha az olması ve artan çevre bilinci ile birlikte daha çevreci bir taşıma olması gibi nedenlerden dolayı kullanıcılar tarafından tercih edilmekte ve yoğun olarak kullanılmaktadır. Taşımacılık faaliyetlerde hizmet kalitesinin arttırılmasının müşteri güvenini nasıl etkilediği önemlidir. Dolayısıyla bu çalışmanın amacı intermodal taşımacılık hizmetlerinde lojistik hizmet kalitesinin müşteri güvenini nasıl etkilediğini saptamaktır. Çalışmada intermodal taşıma hizmeti veren uluslararası bir firmanın 118 kullanııısına ulaşıımıştır. Yapılan regresyon analizi sonucunda lojistik hizmet kalitesinin müşteri güvenini pozitif yönde etkilediği bulgusu elde edilmiştir. LSQ'nun alt boyutlarından olan sipariş teslim miktarı ve sipariş durumu boyutları istatistik olarak anlamlı çıkmamıştır.

Anahtar sözcükler: intermodal taşıma, lojistik hizmet kalitesi, müşteri güveni, regresyon analizi, taşıma, lojistik

\footnotetext{
* Bu çalışma Dr. Aynur Acer danışmanlığında Oktay Güngör tarafından hazırlanan "Intermodal Taşımacılıkta Lojistik Hizmet Kalitesinin Müşteri Sadakati ve Müşteri Güvenine Etkisi" başlıklı yüksek lisans tezinden türetilmiştir.

${ }^{1}$ Sorumlu Yazar: YL Öğrencisi, İstanbul Arel Üniversitesi, Lisansüstü Eğitim Enstitüsü, Uluslararası Ticaret ve Lojistik Bölümü, E-posta: oktaygng@gmail.com, https://orcid.org/0000-0002-0551-3556

${ }^{2}$ Dr., Arel üniversitesi, Iktisadi ve İdari Bilimler Fakültesi, Lojistik Yönetimi, E-posta: aynuracer@arel.edu.tr, https://orcid.org/0000-0002-7315-7020
} 


\title{
The Effect of Logistics Service Quality on Customer Trust and an Application in Intermodal Transport Services*
}

\author{
Oktay Güngör ${ }^{3}$ \\ Aynur Acer ${ }^{4}$
}

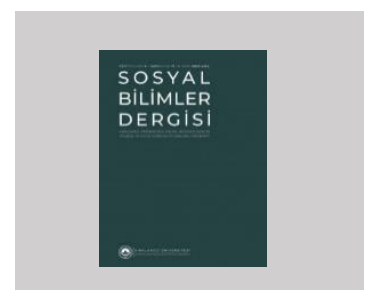

Article Type

Research Article

Submit Date

2021-11-22

Acceptance Date

2021-12-04

DOI

10.47140/kusbder.1027177

\begin{abstract}
Today, intermodal transportation is one of the modes of transportation that has become widespread. In intermodal transportation, where two or more types of transportation are used together without changing the transportation unit, road transportation is used at the beginning and end parts of the voyage that especially short distances. It is preferred and used extensively by users due to reasons such as lower transportation costs compared to single mode transportation and being a more environmentally friendly transportation with increasing environmental awareness. Therefore, the aim of this study is to determine how logistics service quality affects customer trust in intermodal transportation services. In the study, 118 users of an international company providing intermodal transportation services were reached. As a result of the regression analysis, it was found that logistics service quality positively affects customer trust. Order delivery quantity and order status dimensions, which are sub-dimensions of $\mathrm{LSQ}$, were not statistically significant.
\end{abstract}

Key words: intermodal transportation, logistics service quality, customer trust, regression analysis, transportation, logistics

\footnotetext{
*This study is derived from "The effect of logistics service quality on customer trust and customer loyalty in intermodal transportation" master's thesis directed by Oktay Güngör under the supervision of Phd..Aynur Acer.

${ }^{3}$ Corresponding Author: Istanbul Arel University, Postgraduate Education Institute, International Trade and Logistics, E-mail: oktaygng@gmail.com, Https://orcid.org/0000-0002-0551-3556

${ }^{4}$ Phd., Faculty of Economics and Administrative Sciences, Logistics Management, E-mail: aynuracer@arel.edu.tr, Https://orcid.org/0000-0002-7315-7020
} 


\section{Giriş}

Dünya ekonomisi son 20 yıl içerisinde yoğun küreselleşme faaliyetleri ile birlikte büyük yükseliş yaşamıştır. Günümüzde küresel anlamda hizmet veren tedarik zincirleri; ülkeler arası üretim faaliyetlerinde uyuşmazlık, müşterilerin farklı ve faklılaşmaya devam eden ihtiyaç ve talepleri, ürünlerin kısa ömürlü olması, teslimatlardaki hız talebinin karşılanabilmesi, az stok ile çalışma isteği, lojistik faaliyetlerdeki maliyet artışları ve özellikle gelişmekte olan ülkelerde yaşayan insanların yıllık gelirlerindeki azalışlar gibi problemlerle karşı karşıya kalmaktadır. Bu durum küresel dağıtımdaki verimliliği, yeterli ve tam zamanlı ürün tedarikini, hızlı teslimatı ve az stok bulundurmayı zorunlu kılmıştır. Dolayısıyla hem üretime katılacak hem de bitmiş olan ürünlerin bu zincir içerisindeki akışı taşımacılığın değerini arttırmaktadır (Massaroni vd., 2016, s. 46).

1970'ler ve sonrasında lojistik operasyonlar ve taşımacılık sadece askeri alanlarda değil, aynı zamanda dış ticaret faaliyetlerinin gelişimini destekleyerek menşei farklı ürünlerin taşınmasında da kendini göstermiştir. Taşımacılık, karayolu, havayolu, denizyolu, demiryolu, boru hattı ve iç suyolu taşımacılığı olmak üzere kendi içerisinde altı ana moda bölünen bir faaliyettir. Fakat günümüzde gerçekleştirilen taşımacılık faaliyetleri coğrafi koşulların elverişliliği ve ürünün özelliklerine bağlı olarak planlanmaktadır. Tek modlu taşımanın yerine intermodal taşıma gibi birden çok taşıma modunun kullanıldığı taşımalar maliyet avantajı sağlama, güvenilirlik ve çevreye olumsuz etkileri az taşıma olması gibi birçok nedenden dolayı daha çok tercih edilmektedir. Çoklu taşıma türlerinden biri olan intermodal taşımacılık da bunlardan birisidir. Macharis ve Bontekoning (2004), intermodal taşımacılığı, "tek bir taşıma zincirinde, mallar için konteyner değişikliği olmaksızın, rotanın büyük bir kısmının demiryolu, iç su yolu veya okyanusta seyreden gemilerle katedildiği en az iki taşıma modunun birleşimi” olarak tanımlamaktadır. İntermodal taşımalar içinde karayolu taşımaları çok kısa mesafeler için özellikle ilk ve son yolculuklarda kullanılmaktadır.

Yüklerin genel yapısı ve terminallerdeki aktarım hızları hizmet sağlayıcı firmaların lojistik hizmet kalitesini etkilemekte ve bunun için tek modlu taşımalara göre intermodal taşımalara olan eğilim daha fazla görülmektedir (Oflaç ve Uyguç, 2017). Intermodal taşımacılığın entegrasyonuyla yüklerin bir moddan başka bir moda aktarımı sırasında yapılacak olan elleçleme faaliyetlerinin azaltılıp kolaylaşması ve bu bağlamda verimlilik sağlanması amaçlanmıştır (Kasapoğlu ve Cerit, 2011). Özellikle Avrupa'ya yapılan veya Avrupa'dan yapılan intermodal taşımalar da kendi içinde refakatli ve refakatsiz bir şekilde gerçekleşmektedir (Çekerol ve Nalçakan, 2011). Refakatli intermodal taşımada, intermodal taşımada kullanılan swap body, palet, konteyner, vagon, semi treyler gibi taşıma birimlerinin sürücü ile birlikte yolculuğu söz konusuyken refakatsiz intermodal 
taşımada taşıma birimleri sürücüsüz seyahati söz konusudur. Ro-ro ((Roll-on/Roll off) ve Ro-la (Rollende Landstrasse) taşımalarının büyük bir kısmı refakatsiz yapılmaktadır. Bu iki tür değerlendirildiğinde intermodal taşımalarda en çok refakatsiz organizasyonlar tercih edilmektedir ve bu türün kullanım oranı \%70 - \%80 civarındadır.

Son yıllarda uluslararası ticaretin büyümesi, intermodal taşımacılığın kullanımına yönelik eğilimde bir artışa ve bunun sonucunda konuya yönelik araştırma ilgisine yol açmıştır. Sonuç olarak, bu araştırma, verimlilik ve taşıma maliyetleri üzerindeki etkisi ile ulaştırma ekonomisi üzerindeki olumlu etkisi nedeniyle son yıllarda önem kazanmıştır. Tek modlu bir taşımaya kıyasla çok modlu taşımalar taşıma maliyetlerinde \%20'lik bir tasarruf sağlamaktadır ve bu taşımalar ile \%63'lük tren yükleme alanı kullanımı denge noktasına ulaşır (Kordnejad,2014).

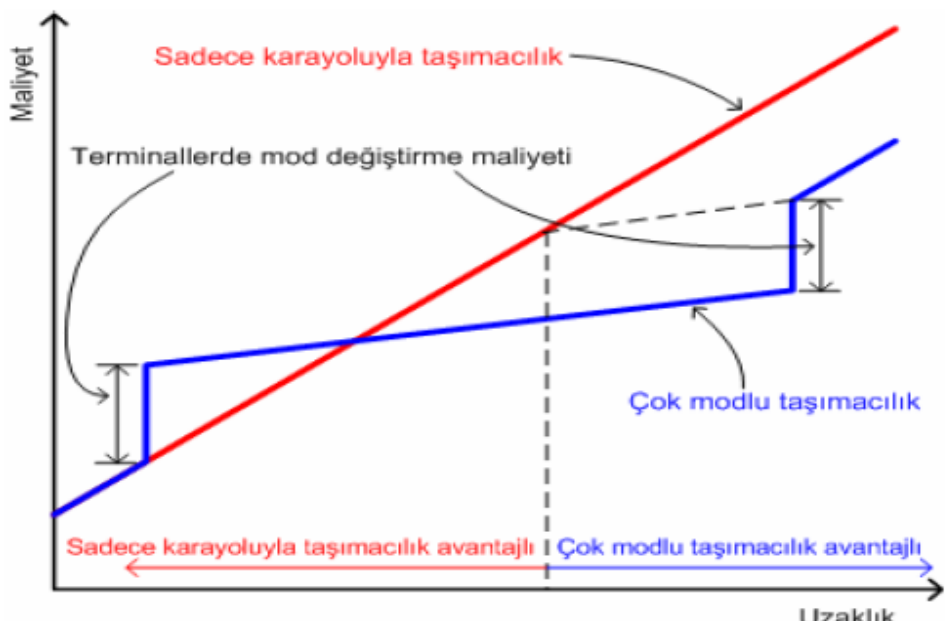

Şekil 1. Tek modlu ve çok modlu (intermodal) taşımacılığın uzaklık-maliyet analizi (Kasapoğlu ve Cerit, 2011, s. 61)

Şekil 1.'de de görüldüğü gibi intermodal taşımacılık tek modlu taşıma türlerinden biri olan karayolu taşımacılığına göre uzaklık arttıkça toplam taşıma maliyeti en uygun olan taşıma türüdür. İntermodal taşımacılığın sadece maliyet avantajı değil aynı zamanda sürdürülebilirlik için çevreci bir taşıma olması da, bu taşıma türünün bir diğer özelliğidir. Intermodal bir sistem, tek modlu bir sisteme kıyasla CO2 emisyonları açısından çevresel etkiyi \%57'ye kadar en aza indirebilir (Craig vd., 2013).

İşletmelerin maliyet minimizasyonu çabalarının yanı sıra CO2 salınımı, çevrecilik hareketlerine artan duyarlıık, sürdürülebilir ve yeşil lojistik tabanına oturtulmuş faaliyetlerin yürütülmesi çabasının intermodal taşımalara yansımasıyla bu taşıma türü 
kendisini sürekli bir gelişim süreci içinde bulmuştur (Rodrigue vd., 2017). Bu gelişim inovatif değişiklikler ve operasyonel çeşitlilikleri beraberinde getirerek, bu alanda lojistik hizmet sağlayan firmalara da bazı görevler yüklemiştir. Yük sahibi ve taşıtan firmalar bu konulara ne kadar duyarlıysa aynı duyarlııı ve çaba, taşıyan ve bu alanda lojistik hizmet veren firmalardan da beklenir hale gelmiştir. Intermodal taşıma faaliyetlerini yürüten firmaların bu hizmetleri sürdürülebilir ve kalıcı kılması için müşterilerine güven veren işletmeler haline gelmesi gerekmektedir. Bu nedenle bu çalışmada intermodal taşımacılık faaliyetlerinde lojistik hizmet kalitesinin müşteri güvenine etkisi araştırılmış ve veriler regresyon yöntemi ile analize tabi tutulmuştur.

Çalışmanın ilerleyen bölümünde kavramsal çerçeveyi oluşturan lojistik hizmet kalitesi ve müşteri güveni açıklanmıştır. Uygulamayı içeren üçüncü bölüm ise Türkiye'de intermodal taşımacılık faaliyetleri gerçekleştiren bir firmanın lojistik hizmet kalitesi ve müşteri güvenine etkisini içermektedir.

\section{Lojistik Hizmet Kalitesi}

Hizmet kalitesi literatürde yapılan tanımlar incelendiğinde Hoffman ve Bateson (1997, s. 298) hizmet kalitesini "uzun vadeli performans değerlendirmeleri sonucunda ortaya çıkan tutum" olarak tanımlamaktadır. Müşteri ile çalışan arasındaki etkileşimin yoğunluğu ile birlikte müşteri beklentilerinin ne derecede karşılandığına dair deneyimler kaliteyi vermektedir. Dolayısıyla hizmet kalitesi "müşteri beklentileri ile deneyimleri arasındaki tutarlılık seviyesi" olarak ifade edilmektedir (Rushton vd., 2010).

Lojistikte performansın artması hizmet kalitesi ile doğru orantılıdır. Lojistik hizmet kalitesi değerlendirilirken hizmete konu olan tüm lojistik faaliyetler bir arada değerlendirilmeli ve kalite boyutunun bütününe bakılmalıdır. Lojistik hizmet kalitesinin boyutları ve özellikleri açısından büyük ölçüde farklıdır. Böylece lojistik hizmet kalitesinin kapsadığı tüm alanların ölçülebilmesi amacıyla Mentzer ve diğerleri 1999 yılında yapmış olduğu çalışmalarında; Parasuraman ve diğerleri tarafından geliştirilen SERVQUAL ölçeğiyle Bienstock ve diğerleri tarafından 1997 yılında geliştirilen PDSQ ölçeklerini birleştirerek, bunlara temel lojistik faaliyetlerle ilgili ölçekleri de eklemiş ve LSQ yani Lojistik Hizmet Kalitesi ölçeğini meydana getirmiştir (Toygar, 2018, s. 78).

Bu sebeple 1999 yılında Mentzer ve diğerleri tarafından geliştirilen, 2001 yılında Hult'un katkılarıyla geliştirilen ve bu çalışmada da ölçek olarak kullanılan lojistik hizmet kalitesi ölçeği bu hizmet kalitesi ölçümünü dokuz boyutta gerçekleştirmektedir (Oskaybaş vd., s. 123):

\section{Zamanındalık}


Ingilizcede "on time delivery" yani "tam zamanlı teslimat" olarak bilinen bu kavram bir lojistik faaliyette ihtiyaç duyulan mal ve hizmetlerin zamanında verilmesi anlamına gelmekte ve tüm faaliyetlerin kalitesini etkileyen faktörlerin başında gelmektedir. Sipariş veren müşteri sadece teslimat sırasında değil aynı zamanda bilginin aktarımı sırasında da zamanı önemsemektedir (Farahani vd., 2011).

\section{Çalışanlararası iletişim kalitesi}

Tedarik zinciri içerisinde kendisine yer bulan hizmet alan ve veren taraflar arası kurulan iletişimin gücü sorun çözme yeteneğini, bilgi aktarım hızını, birimlerin kontrolünü ve mekanizmanın doğru yönetimini direkt olarak etkimektedir (Adebayo, 2017).

\section{Sipariş durumu}

Bu boyut sunulan mal ve hizmetlerin tedarik sürecinden başlayarak teslim edilene kadar oluşması muhtemel hasar ve hataların öngörülerek gerekli önlemlerin alınması ve bu önlemler kapsamında siparişin sürekli olarak kontrol altında tutulması süreci olarak tanımlanmaktadır (Fawcett ve Cooper, 1998).

\section{Sipariş prosedürleri}

Bir müşterinin ihtiyaç duyduğu mal ve hizmete ulaşma adımları olarak adlandırılan bu boyut her bir adımda ayrı ayrı uygulanan prosedürleri, sipariş edilen mal veya hizmetin doğru bir şekilde, zamanında ve hasarsız olarak teslim edilmesini içermektedir (Rinehart vd., 1989).

\section{Sipariş uyuşmazlıkları yönetimi}

Talep edilen mal ve hizmetle ilgili herhangi bir aksaklık, yanlışlık veya uyuşmazlık durumunda müşteriler, tedarikçilerin tutum ve davranışları ile sorun çözme yeteneklerinin ön plana çıkmasını beklerler. Yanlışların çözüme kavuşma hızı ve doğruluğu karşılığında siparişlerin tekrarlanması müşterinin yaşadığı memnuniyet seviyesini gösterir. Memnun kalınması durumunda siparişlere devam edilirken, çözülemeyen sorunlar sebebiyle yaşanan mutsuzluk siparişin tekrarlanmaması süreciyle son bulacaktır (Flint ve Gammelgaard, 2007).

\section{Sipariş teslim miktarı}

Talep edilen mal veya hizmetin doğru, zamanında ve hasarsı tesliminin yanında ulaşılabilir olması da müşteri memnuniyetini olumlu etkilemektedir. Dolayısıyla güçlü bir tedarik alt yapısına sahip olunarak ürüne ulaşılabilirlik gücünün arttırılması gerekmektedir (Turban vd., 2018). 


\section{Sipariş kalitesi}

İhtiyaç duyulan bir mal veya hizmetin taleplere uygunluğu ve gereksinimleri karşılama seviyeleri o siparişin kalitesini ölçmektedir. Gerçekten ihtiyaç duyulup duyulmadığı veya hangi ihtiyacın karşılanması gerektiği doğru belirlenmeli ve siparişler buna göre oluşturulmalıdır (Mentzer vd., 2001).

\section{Siparişin doğruluğu}

Müşteri tarafından sipariş edilen bir ürün veya hizmetin miktar ve niteliğinin belirlenerek tedarik sürecine geçilmesi aşamasıdır.

\section{Bilgi kalitesi}

Bilgi kaynağının anlaşılır olması, bilgiyi aktaracak olan kişilerin doğru anlaması ve buna paralel olarak doğru aktarabilmesi için oldukça önemlidir. Yeterince ulaşılabilir ve kaliteli bilgi, müşterinin satın alma kararlarına direkt olarak etki eder. Satın alma mekanizmasını harekete geçirerek hizmeti talep eden kişinin doğru hizmete yönlendirilmesi amaçlanır (Mentzer vd., 2001).

\section{Müşteri Güveni}

Güven kavramı psikoloji, antropoloji, tarih, pazarlama, sosyoloji, kamu ve özel yönetimler gibi sosyal bilimlerin pek çok alanında incelenmiş ve bu alanlarda çalışma yapan kişiler tarafından tanımlanmıştır. Bu yönüyle güven kendisine çok geniş yelpazede yer bulan bir kavramdır. Özellikle mesleki alanlar açısından ele alındı̆̆ında psikologlar güveni bireysel anlamda değerlendirirken, sosyologlar güvene kamusal bir alan çizer ve bu çerçevede değerlendirir. Yönetim alanında yapılan çalışmalarda güven bireysel olarak ele alınırken, bu sefer kişinin kendisi değil daha çok çevresi tarafından nasıl görüldüğü konusu üzerinde durulur. Pazarlama alanında yapılan çalışmalarda güven, bireysel beklentiler üzerinden değerlendirerek aslında var olmayan bir şey üzerinden bir kişinin başka kişiler üzerindeki varsayımları ve buna bağlı niyetleri olarak kavramsallaştırılmaktadır (Kim vd., 2004, s. 394).

Murphy ve Knemeyer (2016, s. 115) güven kavramını "insan etkileşimleri ve bu etkileşimler sonucu değişimleri içeren bir olgu" olarak tanımlamakta ve güvenin bir inanma ihtiyacı olduğunu vurgulamaktadır. Müşteri güveni kazanımı çok zor ama kaybedilmesi çok kolay olan bir süreçtir. Güven duygusunun gelişimi sırasında elde edilen kazanımlar tüm sürecin uzunluğu ve bu süreç içerisinde yaşanan olayların sağlam temellere dayanması sayesinde kaybedilme veya eksilme yaşanacağı durumlara da direkt etki eder. Kişiler veya kurumlar bu süreçleri ne kadar sağlıklı geçirirse olumsuzlukları aşmak bir o kadar hızlı ve kolay olacaktır (Saraçoğlu, 2013). 
Raimondo (2000) güven algısının yetenekler ve güdüler temelinde oturtulduğunda açıklanabilir olduğunu ifade etmiş; yetenek ve güdüler endeksinde algıların olumlu veya olumsuz olması ile motivasyon algısının yüksek veya düşük seyretmesi sonucunda dört farklı kategoriye ayrılabileceğini dile getirmiştir.

\begin{tabular}{|c|c|c|c|}
\hline & & \multicolumn{2}{|c|}{ YETENEK } \\
\hline & & Yüksek & Düşük \\
\hline \multirow{2}{*}{ 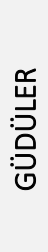 } & $\frac{\text { 믈 }}{\frac{5}{\partial}}$ & Mutlak Güven & Umut Vadeden Güven \\
\hline & $\begin{array}{l}\text { ปั } \\
\text { 气ิ } \\
\frac{\partial}{0}\end{array}$ & Stabil Olmayan Güven & Güvensizlik \\
\hline
\end{tabular}

Şekil 2. Güven Türleri (Raimondo, 2000)

Şekil 2.'de de görüldüğü gibi yetenek algısının yüksek ve motivasyonun olumlu olması durumda "mutlak güven"; yetenek algısının düşük ve motivasyonun olumlu olması durumunda "Umut vadeden güven"; motivasyonun olumsuz ve yetenek algısının yüksek olduğu durumda "Stabil olmayan güven" ve son olarak motivasyonun yine olumsuz ve yetenek algısının düşük olduğu durumda "Güvensizlik" ortaya çıkmaktadır.

Müşteri güveni tek taraflı ortaya çıkan bir olgu değildir. Güven, hem müşterinin işletmeye hem de işletmenin müşteriye karşılıklı olarak verdiği vaatleri gerçekleştirebilme gücü ve bu oluşum içerisinde geçen süre olarak adlandırılmaktadır (Doney ve Canon, 1997, s. 42). İşte bu noktada verilen sözlerin yerine getirilmesi sonucunda sağlanan fayda ile doğru orantılı olarak taraflar arasında güven kavramı gelişme kaydetmektedir (Hallikainen ve Laukkanen, 2018).

\section{IIgili Araştırmalar}

Lojistik, günümüzde rekabetin yoğun yaşandığı iş dünyasında müşteriye yer ve zaman faydası sağlayarak ürün veya hizmetlerin müşterilere ulaşmasında fiziksel dağıtımın planlanmasına destek olmakta ve hizmet kalitesine katkıda bulunan önemli bir faaliyet olarak görülmektedir (Uzel ve Tuna, 2014). Literatürde lojistik hizmet kalitesi ile ilgili yapılan çalışmalar ağırlıklı olarak elektronik ticaret hizmetlerinde yer almaktadır. Lojistik hizmet kalitesinin ölçülmesiyle ilgili yapılan çalışmalardan bazıları şunlardır:

Grönroos (1984)'un müşteriler tarafından hizmet kalitesinin nasıl algılandığını konu edinerek bir model ortaya koyduğu çalışma, hizmet kalitesiyle ilgili yapılan ilk çalışmalardandır. Sonrasında Parasuraman vd. (1985) yapmış oldukları çalışmada hizmet 
kalitesini 10 boyutta değerlendirerek ilerleyen yıllarda beş boyuta düşürmüş ve SERVQUAL ölçeğinin gelişmesine katki sağlamıştır. Mentzer vd. (1989) lojistik hizmet kalitesini kullanılabilirlik, zamanındalık ve kalite olarak çalışmalarında üç boyutta değerlendirmiştir.

Maltz ve Maltz (1998) lojistik hizmet kalitesinin algısal tarafına dikkat çekmiş olduğu çalışmasında, hizmet sunan çalışanların davranışlarının hizmetin kalitesi üzerinde pozitif etkisi olduğunu öne sürmüş ve çalışanların iletişim gücü, problem çözme gücü ve empati yeteneğinin hizmet kalitesine olumlu etki ettiğini belirtmiştir.

Orel vd. (2012) 195 sanayi işletmesini konu ettiği çalışmalarında lojistik hizmetlerde algılanan hizmet kalitesinin müşteri tatminine etkisini araştırmıştır. Araştırmada sipariş hizmetleri, bu hizmetlerin kalitesi, ilişkisel hizmetlerin müşteri tatminini pozitif yönde etkilediği belirtilmiştir.

Uzel ve Tuna (2014) çalışmasında Mentzer vd. (1999) tarafından geliştirilen lojistik hizmet kalitesi (LSQ) ölçeğini yargısal örnekleme yöntemiyle elektronik alış veren kullanıcılar üzerinde uygulamıştır. Çalışma sonucunda sipariş süreci kolaylığı, sipariş izlenebilirlik imkanı ve teslimat durumunun satış sonrası davranışsal niyeti etkilediği bulgusu elde edilmiştir.

Karadeniz ve Işık (2014) çalışmasında e-ticarette lojistik hizmet kalitesinin müşteri memnuniyetine etkisi araştırılmıştır. Faktör, anova ve regresyon analizlerinin yöntem olarak kullanıldığı çalışmada aynı zamanda demoğrafik değişkenlerin lojistik hizmet kalitesi boyutları ve müşteri memnuniyeti algılamalarında farklılık gösterip göstermediği incelemeye tabi tutulmuştur. Lojistik hizmet kalitesinin tüm alt boyutlarının müşteri memnuniyeti üzerinde pozitif etkileri olduğu bulgusu elde edilmiştir.

Bakan ve Şekkeli (2018) çalışmalarında Kahramanmaraş ilinde farklı alanlarda hizmet veren ve lojistik faaliyetlerini dış kaynak yoluyla gideren firmaların aldıkları lojistik hizmetin kalitesini alt boyutlarda değerlendirmiştir. Operasyonel, personel ve teknik hizmet kalitesi boyutlarının firma sadakatini pozitif yönde ve anlamlı bir şekilde etkilediği bulgusu elde edilmiştir.

Yıldız (2018) lojistik hizmet kalitesinin e-ticaret kullanıcılarının tatmin ve davranışsal niyetine etkisini konu edindiği çalışmasında yöntem olarak yapısal eşitlik modelini kullanmıştır. Çalışmada lojistik hizmet kalitesinin müşteri tatmin duygusunu, müşteri tatminininde davranışsal niyeti pozitif yönde etkilediği bulgusu elde edilmiştir.

Yıldız (2020) çalışmasında e-ticaret sektöründe faaliyet gösteren işletmelerin lojistik hizmet kalitesinin müşteri güveni, memnuniyeti ve sadakatine etkisini araştırmıştır. 423 e-ticaret kullanıcısını konu alan çalışmada yapısal eşitlik modeli kullanılarak lojistik hizmet 
kalitesinin memnuniyet ve güveni pozitif yönde etkilediği ve sadakati anlamlı bir şekilde etkilemediği sonucu elde edilmiştir.

Elektronik ticarette lojistik hizmet kalitesinin müşteri memnuniyeti ve sadakatine etkisinin tartışıldığı bir diğer çalışmada açıklayıcı faktör ve regresyon analizleri yöntem olarak kullanılmıştır. Çalışmada lojistik hizmet kalitesinin müşteri memnuniyeti ve sadakatini pozitif yönde etkilediği sonucu ortaya çıkmış ve aldıkları üründen memnun olan kullanıcıların sadakatlerinde de artış olduğu tespit edilmiştir (ilhan, 2021).

Lojistik regresyon analizini kullanarak Erzincan'da faaliyet gösteren imalat işletmelerinde lojistik hizmet kalitesinin verimliliğe etkisini araştıran Korucuk (2018), lojistik hizmet kalitesi boyutlarından personel iletişim, bilgi, sipariş işleme, fiziksel dağıtım ve teknoloji kalitesinin verimlilik üzerinde pozitif etkisi olduğunu elde etmiştir.

Taşımacılık alanında lojistik hizmet kalitesi ile ilgili yapılan çalışmalardan bazıları ise şunlardır:havayolu taşımacılığında hizmet kalitesinin kurumsal imaj, müşteri memnuniyeti ve müşteri sadakatine etkisi (Yangınlar ve Tuna, 2020), havayolu ulaşımında hizmet kalitesinin ölçülmesi ile ilgili iç katlarda bir uygulama (Hatipoğlu ve Işık, 2015) ve demiryolu hizmetlerindeki kalitenin ödenen ücret açısından müşteri tatminine etkisi (Seçilmiş vd., 2001). Literatür incelendiğinde intermodal taşımada lojistik hizmet kalitesinin değerlendirilmesiyle alakalı bir çalışmaya rastlanmamıştır. Bu nedenle bu çalışmada kullanılan ölçek intermodal taşımacılık alanında uygulanmış ve sonuçları değerlendirilmiştir.

Müşteri güveni ile ilgili literatürde yapılan çalışmalardan bazıları ise şu şekilde sıralanmaktadır: Siau ve Shen (2003) yapmış oldukları çalışmasında müşterilerin satın alma faaliyetini gerçekleşeceği işletme seçiminde, bu işletmelerin satış yeteneği, müşterilerine karşı olan dürüst tavrı ve ilgisinin yeterli olmadığı sonucunu elde etmiştir. Müşterinin bir ürünü satın alması üzerine oluşan isteği ve buna bağlı olan motivasyonu, satın alma faaliyetinin büyük oranda hızına etki etmektedir.

Hacıefendioğlu ve Çolular (2008) çalışmalarında müşteri güveninin oluşmasında sağlam kişisel ilişkiler ve yapılan iş birliklerinin direkt etkili olduğu bulgusunu savunmuş ve müşteri güvenini etkileyen altı faktör olduğunu ifade etmiştir. Bu faktörler şunlardır: Somut varlıklar, güven aşılama, isteklilik, tavsiye edilme, ambiyans, empati.

Martinez ve Del Bosque (2013) otel işletmeleri üzerine yapmış olduğu çalışmasında müşteri güveninin sadece toplamsal çıkarları konu alan faaliyetlerde değil aynı zamanda bireysel anlamda güveni de tetikleyici unsurlara sahip olduğunu belirtmektedir.

Suhartanto vd. (2019) çalışmalarında bir fast food dükkanının tercih edilme sebeplerine dikkat çekmiş ve müşteri güveninin risk algısı ile daha çok bağlantılı olduğu sonucuna 
varmıştır. Risk almak istemeyen müşterilerin o işletmeye daha çok güvendiği ve buna bağlı olarak daha çok tercih ettikleri ifade edilmiştir.

Bir başka çalışmada Atılgan ve Alhussein (2021) özellikle çevrim içi alışverişin yoğun yaşandığı günümüzde bir internet sitesinin tasarımının müşteri güveni, memnuniyeti ve satın alma niyetine etkisini araştırmıştır. 441 üniversite öğrencisinin örneklem alındığı çalışmada bilgi tasarımı, grafik tasarımı ve navigasyon tasarımının müşteri güveni memnuniyetini pozitif yönde etkileyerek satın alma davranışına dönüşmede önemli bir etkisinin olduğu tespit edilmiştir.

\section{Yöntem}

Çalışmanın uygulama kısmında günümüzde yoğun olarak kullanılan taşımacılık faaliyetlerinden biri olan intermodal taşımacılık hizmetlerinde lojistik hizmet kalitesinin müşteri güvenine etkisi araştırılmış ve elde edilen veriler regresyon modeli ile analize tabi tutulmuştur.

\section{Araştırmanın Modeli ve Hipotezi}

Bu çalışmada lojistik hizmet kalitesi ve müşteri güveni konuları bir arada değerlendirilmiştir. Çalışmada intermodal taşımacılık sektöründe faaliyet gösteren bir firmanın müşterilerine anket yoluyla ulaşılmış ve kolayda örnekleme yöntemi kullanılarak 118 kullanıcının cevabı ile veriler toplanmıştır. Anket kısmı üç bölümden oluşmaktadır. illk bölümde firma bilgilerini içeren demografik özellikleri konu edinen sorulara yer verilmiştir. İkinci bölümde 1999 yılında Mentzer, Flint ve Kent tarafından meydana getirilen ve 2001 yılında Mentzer, Flint ve Hult'un katkılarıyla geliştirilen dokuz alt boyut ve toplamda 25 ifadeden oluşan lojistik hizmet kalitesi ölçeği (LSQ, Logistic Service Quality) kullanılmıştır. LSQ ölçeğinin alt boyutları şu şekilde sıralanmaktadır: zamanındalık, çalışanlar arası ilişki kalitesi, sipariş durumu, sipariş prosedürleri, sipariş uyuşmazlıkları yönetimi, sipariş teslim miktarı, sipariş kalitesi, siparişin doğruluğu, bilgi kalitesi. Anketin son bölümünde ise müşteri güveni konusunda Mosavi ve Ghaedi (2012) tarafından geliştirilen ve beş ifadeden oluşan ölçeğe yer verilmiştir. Kullanılan ölçekler "kesinlikle katılmıyorum" (1)'den "kesinlikle katılıyorum" (5) şeklinde beşli likert formatında ifadeleri içermektedir. Araştırmanın modeli aşağıdaki gibidir: 


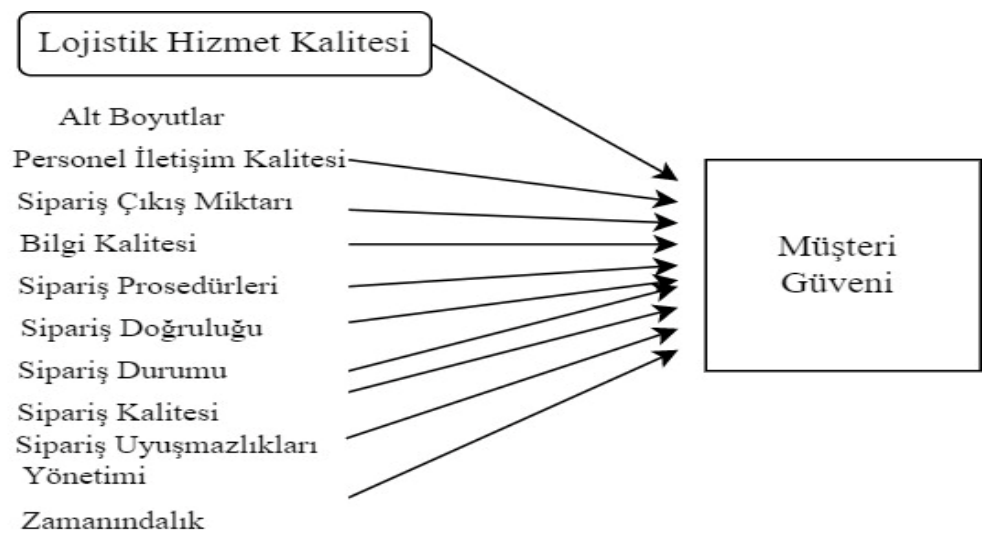

Şekil 3. Araştırmanın Modeli

Araştırmanın hipotezi lojistik hizmet kalitesinin müşteri güvenine istatistik anlamlı etkisinin olduğu yönündedir ve bunu analiz etmek için regresyon modeli kullanılmıştır. Oluşturulan ana hipotez ve alt hipotezler şu şekildedir:

$\mathrm{H}_{1} \quad$ Lojistik hizmet kalitesi (LHK) ve müşteri güveni (MG) istatistik anlamlı ilişkilidir. Personel iletişim kalitesi alt boyutu ile müşteri güveni istatistik anlamlı $\mathrm{H}_{11}$ ilişkilidir.

$\mathrm{H}_{12}$ Sipariş çıkış miktarı alt boyutu ile müşteri güveni istatistik anlamlı ilişkilidir.

$\mathrm{H}_{13} \quad$ Bilgi kalitesi alt boyutu ile müşteri güveni istatistik anlamlı ilişkilidir.

$\mathrm{H}_{14}$ Sipariş prosedürleri alt boyutu ile müşteri güveni istatistik anlamlı ilişkilidir.

$\mathrm{H}_{15}$ Sipariş doğruluğu alt boyutu ile müşteri güveni istatistik anlamlı ilişkilidir.

$\mathrm{H}_{16}$ Sipariş durumu alt boyutU ile müşteri güveni istatistik anlamlı ilişkilidir.

$\mathrm{H}_{17}$ Sipariş kalitesi alt boyutU ile müşteri güveni istatistik anlamlı ilişkilidir. Sipariş uyuşmazlıkları yönetimi alt boyutu ile müşteri güveni istatistik anlamlı $\mathrm{H}_{18}$ ilişkilidir.

$\mathrm{H}_{19}$ Zamanındalık alt boyutu ile müşteri güveni istatistik anlamlı ilişkilidir.

Çalışmaya katılan kişilerin ölçek dahilinde bulunan soruları cevaplarken gerçek duygu ve düşüncelerini ifade ettikleri göz önünde bulundurulmuştur. Katılımcıların ankete herhangi bir zorlama olmadan yanıt verdikleri, anketi doğru ve eksiksiz bir şekilde yanıtlandırdıkları kabul edilmiştir. Anketler 05.03.2021-16.05.2021 tarihleri arasında internet üzerinden yapılmıştır. Verilerin değerlendirilmesinde IBM SPSS 25.0 paket programı ve Eviews 10.0 sürümü kullanılmış ve sonuçları yorumlanmıştır. 


\section{Bulgular}

Çalışmada analiz öncesinde ölçeklerin güvenilirliği test edilmiştir. Güvenilirlik analizinde en çok kullanılan yöntemlerden biri olan Cronbach Alpha testi kullanılmış ve Cronbach Alpha değeri 0,961 olarak elde edilmiştir. Bu değerin 0,70'den fazla olması ölçeğin güvenilir olduğunu göstermektedir. Analiz süreci ise üç bölümden oluşmaktadır. Birinci bölümde firma özellikleri ve genel bilgilere ilişkin yüzde ve sıklık dağılımları şu şekildedir:

Tablo 1. Cinsiyete ilişkin frekans ve yüzde değerleri

\begin{tabular}{lll}
\hline Cinsiyet & $\mathrm{Fi}$ & $\%$ \\
\hline Kadın & 45 & 38,1 \\
\hline Erkek & 73 & 61,9 \\
\hline Toplam & 118 & 100 \\
\hline
\end{tabular}

118 katılımcıya yönelik demografik ve genel bilgiler sıklık ve yüzde dağılım bilgileri talep edilmiştir. Çalışmaya katılım sağlayan çalışanların \%61,9’u erkek iken \%38,1'i kadındır.

Tablo 2. Eğitim durumuna ilişkin frekans ve yüzde değerleri

\begin{tabular}{lll}
\hline Eğitim Durumu & $\mathrm{Fi}$ & $\%$ \\
\hline İlköğretim & 3 & 2,5 \\
\hline Ortaöğretim & 7 & 5,9 \\
\hline Ön lisans & 19 & 16,1 \\
\hline Lisans & 55 & 46,6 \\
\hline Lisansüstü & 32 & 27,1 \\
\hline Doktora & 2 & 1,7 \\
\hline Toplam & 118 & 100 \\
\hline
\end{tabular}

Çalışmaya katılan katılımcıların eğitim durumları Tablo 2.'ye göre ele alındığında $\% 46,6^{\prime}$ sının lisans, \%27,1'inin lisansüstü, \%16,1'inin ön lisans, \%5,9'unun ortaöğretim, $\% 2,5^{\prime}$ inin ilköğretim ve son olarak \%1,7'si doktoradır.

Tablo 3. Katılımcıların görev düzeyineilişkin frekans ve yüzde değerleri

\begin{tabular}{lll}
\hline Görev Düzeyi & $\mathrm{Fi}$ & $\%$ \\
\hline Uzman & 44 & 37,3 \\
\hline Üst Düzey Yönetici & 31 & 26,3 \\
\hline Orta Düzey Yönetici & 32 & 27,1 \\
\hline Teknik Personel & 11 & 9,3 \\
\hline Toplam & 118 & 100 \\
\hline
\end{tabular}


Çalışmaya katılan katılımcıların çalıştıkları firmalardaki görev düzeylerine ilişkin bilgiler değerlendirildiğinde \%37,3'ünün uzman, \%27,1'inin orta düzey yönetici, \%26,3'ünün üst düzey yönetici ve \%9,3’ünün teknik personel olduğu tespit edilmiştir.

Tablo 4. Katılımcıların çalıştıkları departmana ilişkin frekans ve yüzde değerleri

\begin{tabular}{lll}
\hline Departman & $\mathrm{Fi}$ & $\%$ \\
\hline Lojistik/ tedarik zinciri/ operasyon & 43 & 36,4 \\
\hline Dış ticaret/ ithalat/ ihracat & 31 & 26,3 \\
\hline Muhasebe/ finans & 14 & 11,9 \\
\hline Satın alma & 11 & 9,3 \\
\hline Satış/ pazarlama & 14 & 11,9 \\
\hline Üretim & 5 & 4,2 \\
\hline Toplam & 118 & 100 \\
\hline
\end{tabular}

Çalıştıkları departmanlara ait bilgiler incelendiğinde ankete katılan çalışanların \%36,4'ünün çalıştığı departman lojistik/tedarik zinciri/ operasyon, \%26,3'ünün dış ticaret/ ithalat/ ihracat, \%11,9'unun satış/ pazarlama, \%11,9'unun muhasebe/ finans, \%9,3'ünün satın alma, ve $\% 4,2$ 'sinin ise üretimdir.

Tablo 5. Katılımcıların çalıştıkları firma faaliyet süresine ilişkin frekans ve yüzde değerleri

\begin{tabular}{lcc}
\hline Firma Faaliyet Süresi & $\mathrm{Fi}$ & $\%$ \\
\hline $0-3$ yıl & 10 & 8,5 \\
\hline $4-7$ yıl & 12 & 10,2 \\
\hline $8-11$ yıl & 16 & 13,6 \\
\hline $12-15$ yıl & 11 & 9,3 \\
\hline $16-19$ yıl & 8 & 6,8 \\
\hline 20 yıl ve üzeri & 61 & 51,7 \\
\hline Toplam & 118 & 100 \\
\hline
\end{tabular}

Ankete katılan katılımcıların çalıştığı firmada hizmet süreleri değerlendirildiğinde $\% 51,7$ 'sinin 20 yıl ve üzerinde çalıştığı belirlenmiş ve bu sıralamayı \%13,6 ile 8-11 yıl, $\% 10,2$ ile 4-7 yıl, \%9,3 ile 12-15 yıl, \%8,5 ile 0-3 yıl ve son olarak \%6,8 ile 16-19 yıl takip etmektedir. 
Tablo 0. Firmada çalışan personel sayısı frekans ve yüzde değerleri

\begin{tabular}{lll}
\hline Firma Personel Sayısı & $\mathrm{Fi}$ & $\%$ \\
\hline 1 -10 kişi & 15 & 12,7 \\
\hline $11-25$ kişi & 28 & 23,7 \\
\hline $26-49$ kişi & 14 & 11,9 \\
\hline $50-99$ kişi & 15 & 12,7 \\
\hline $100-249$ kişi & 14 & 11,9 \\
\hline $250-499$ kişi & 14 & 11,9 \\
\hline 500 kişi ve üzeri & 18 & 15,3 \\
\hline Toplam & 118 & 100 \\
\hline
\end{tabular}

Firmada çalışan personel sayısı özelliği dikkate alındığında \%23,7'si 11-25 kişi, \%15,3'ü 500 kişi ve üzerinde \%12,7'si 1-10 kişi, \%12,7'si 50-99 kişi, \%11,9'u 26-49 kişi, \%11,9'u 100-249 kişi ve \%11,9’u 250-499 aralığında personelden oluştuğu görülmüştür.

Tablo 7. Firma sermaye yapısı frekans ve yüzde değerleri

\begin{tabular}{lll}
\hline Firma Sermaye Yapısı & Fi & \% \\
\hline$\% 100$ Yerli & 75 & 63,6 \\
\hline \%100 Yabancı & 18 & 15,3 \\
\hline Yerli-Yabancı Ortaklığı & 25 & 21,2 \\
\hline Toplam & 118 & 100 \\
\hline
\end{tabular}

Anketin uygulandığı katılımcıların çalıştığı firmaların sermaye yapısı incelendiğinde katılımcıların \%63,6'sının firma sermaye yapısı \%100 yerli, \%21,2'sinin yerli-yabancı ortaklığına sahip ve \%15,3'ünün \%100 yabancı sermayeye sahip işletmelerde çalıştığı elde edilmiştir. 
Tablo 8. Firmaların bağlı bulunduğu sektöre ilişkin frekans ve yüzde değerleri

\begin{tabular}{lll}
\hline Firma Sektörü & $\mathrm{Fi}$ & $\%$ \\
\hline Kağıt, Kağı Ürünleri ve Basım Sanayi & 5 & 4,2 \\
\hline Metal Eşya, Makine, Teçhizat ve Mesleki Aletler Sanayi & 3 & 2,5 \\
\hline Taşımacılık, Gümrükleme ve Diğer Tüm Lojistik Faaliyetler & 44 & 37,3 \\
\hline Kimya, Petrol Ürünleri, Lastik ve Plastik Sanayi & 12 & 10,2 \\
\hline Gıda, İçki ve Tütün Sanayi & 15 & 12,7 \\
\hline Madencilik ve Taş Ocakçı̆ı̆ı & 4 & 3,4 \\
\hline Orman Ürünleri ve Mobilya Sanayi & 6 & 5,1 \\
\hline Metal Ana Sanayi & 5 & 4,2 \\
\hline Dokuma, Tekstil Ürünleri, Deri ve Ayakkabı Sanayi & 9 & 7,6 \\
\hline Elektrik ve Enerji Sektörü & 1 & 0,8 \\
\hline Diğer İmalat Sanayi & 6 & 5,1 \\
\hline Taşıt Araçları Sanayi & 8 & 6,8 \\
\hline Toplam & 118 & 100 \\
\hline
\end{tabular}

Ankete katılan kullanıcıların \%37,3'ü taşımacılık, gümrükleme ve diğer tüm lojistik faaliyetlerde, \%12,7'sinin gıda, içki ve tütün sanayide, $\% 10,2$ 'sinin kimya ,petrol ürünleri, lastik ve plastik sanayide, \%7,6'sının dokuma, tekstil ürünleri, deri ve ayakkabı sanayide, $\% 6,8^{\prime}$ inin taşıt araçları sanayisinde, \%5,1'inin diğer imalat sanayisinde, \%5, $1^{\prime}$ inin orman ürünleri ve mobilya sanayide, $\% 4,2$ 'sinin metal ana sanayide, $\% 4,2$ 'sinin çalıştığı firma sektörü kağıt, kağıt ürünleri ve basım sanayide, \%3,4'ünün madencilik ve taş ocakçılığında, $\% 2,5^{\prime}$ inin metal eşya, makine, teçhizat ve mesleki aletler sanayinde ve \%0,8'inin elektrik ve enerji sektöründe faaliyet gösterdiği elde edilmiştir.

Tablo 9. Firma lojistik harcama payına ilişkin frekans ve yüzde değerleri

\begin{tabular}{lll}
\hline Lojistik Harcama Payı & $\mathrm{Fi}$ & $\%$ \\
\hline$\%$ 0-10 & 28 & 23,7 \\
\hline \% 11-25 & 37 & 31,4 \\
\hline$\%$ 26-50 & 22 & 18,6 \\
\hline$\%$ 51-75 & 7 & 5,9 \\
\hline \% 76-100 & 24 & 20,3 \\
\hline Toplam & 118 & 100 \\
\hline
\end{tabular}

Kullanıcıların çalıştıkları firmaların toplam harcamalar içindeki lojistik payları değerlendirildiğinde \%31,4'ünün \%11-25 arasında, \%23,7'sinin toplam harcamalar içerisindeki lojistik harcama payı \%0-10 arasında, \%20,3'ünün \%76-100 arasında , \%18,6'sının \%26-50 arasında ve \%5,9'unun \%51-75 arasında olduğu görülmüştür. 
Tablo 10. Firmanın kullandığı intermodal taşımacılık türlerine göre frekans ve yüzde değerleri

\begin{tabular}{lll}
\hline Intermodal Türleri & $\mathrm{Fi}$ & $\%$ \\
\hline Demiryolu Konteyner & 38 & 32,2 \\
\hline RO-RO & 10 & 8,5 \\
\hline RO-LA & 4 & 3,4 \\
\hline Demiryolu Konteyner+RO-RO+RO-LA & 24 & 20,3 \\
\hline Demiryolu Konteyner+RO-RO & 28 & 23,7 \\
\hline Demiryolu Konteyner+RO-LA & 9 & 7,6 \\
\hline RO-RO+RO-LA & 5 & 4,2 \\
\hline Toplam & 118 & 100 \\
\hline
\end{tabular}

Kullanıcıların çalıştıkları firmaların \%32,2'si intermodal taşımacılık türü olarak demiryolu konteyner, \%23,7'si demiryolu konteyner+RO-RO, \%20,3'ü demiryolu konteyner+RORO+RO-LA, \%8,5'i RO-RO, \%7,6'sı demiryolu konteyner+RO-LA, \%3,4'ü RO-LA ve \%4,2'si RO-RO+RO-LA kullanmaktadır.

Tablo 11. Firmanın kullandığı intermodal taşımacılık süresine ilişkin frekans ve yüzde değerleri

\begin{tabular}{lll}
\hline Intermodal Süresi & $\mathrm{Fi}$ & $\%$ \\
\hline 2 yıldan az & 21 & 17,8 \\
\hline $2-5$ yıl & 30 & 25,4 \\
\hline $6-10$ yıl & 25 & 21,2 \\
\hline 10 yıldan fazla & 42 & 35,6 \\
\hline Toplam & 118 & 100 \\
\hline
\end{tabular}

Ankete katılan katılımcıların çalıştıkları firmaların \%35,6'sı intermodal taşımacılık faaliyetlerini 10 yıldan fazla süredir, \%21,2'si 6-10 yıldır, \%25,4'ü 2-5 yıldır ve \%17,8'i lojistik operasyonlarda intermodal taşımacılık hizmetlerini 2 yıldan az süredir kullanmaktadır.

Tablo 12. Firmanın lojistik faaliyetler içinde intermodal taşımacılığın payı

\begin{tabular}{lll}
\hline Intermodal Payı & $\mathrm{Fi}$ & $\%$ \\
\hline$\% 10$ 'dan az & 48 & 40,7 \\
\hline$\% 11-25$ & 27 & 22,9 \\
\hline$\% 26-50$ & 21 & 17,8 \\
\hline$\% 51-75$ & 13 & 11,0 \\
\hline$\% 76-100$ & 9 & 7,6 \\
\hline Toplam & 118 & 100 \\
\hline
\end{tabular}


Son olarak katılımcıların çalıştıkları firmaların \%40,7'sinin lojistik faaliyetlerindeki intermodal taşımacılığın payı \%10'dan az, \%22,9'unun \%11-25 arasında, \%17,8'inin \%2650 arasında, \%11,0'inin \%51-75 arasında ve \%7,6'sının \%76-100 arasındadır.

İkinci bölümde lojistik hizmet kalitesi ve müşteri güveni ölçeğinde yer alan her bir ifadeye ilişkin katılımcıların verdiği cevapların \% olarak karşılı̆ı, ortlamaları ve standart sapmalarına yer verilmiştir. Çalışmada beşli Likert ölçeği kullanılmış ve verilen cevaplar (1) kesinlikle katılmıyorum...(5) kesinlikle katılıyorum şeklinde kodlanmıştır. Lojistik hizmet kalitesi sıklık dağılım tablosu aşağıda Tablo 13. 'de yer almaktadır.

Tablo 13. Lojistik hizmet kalitesi ölçeği boyutlarına yönelik sıklık dağıım analizi

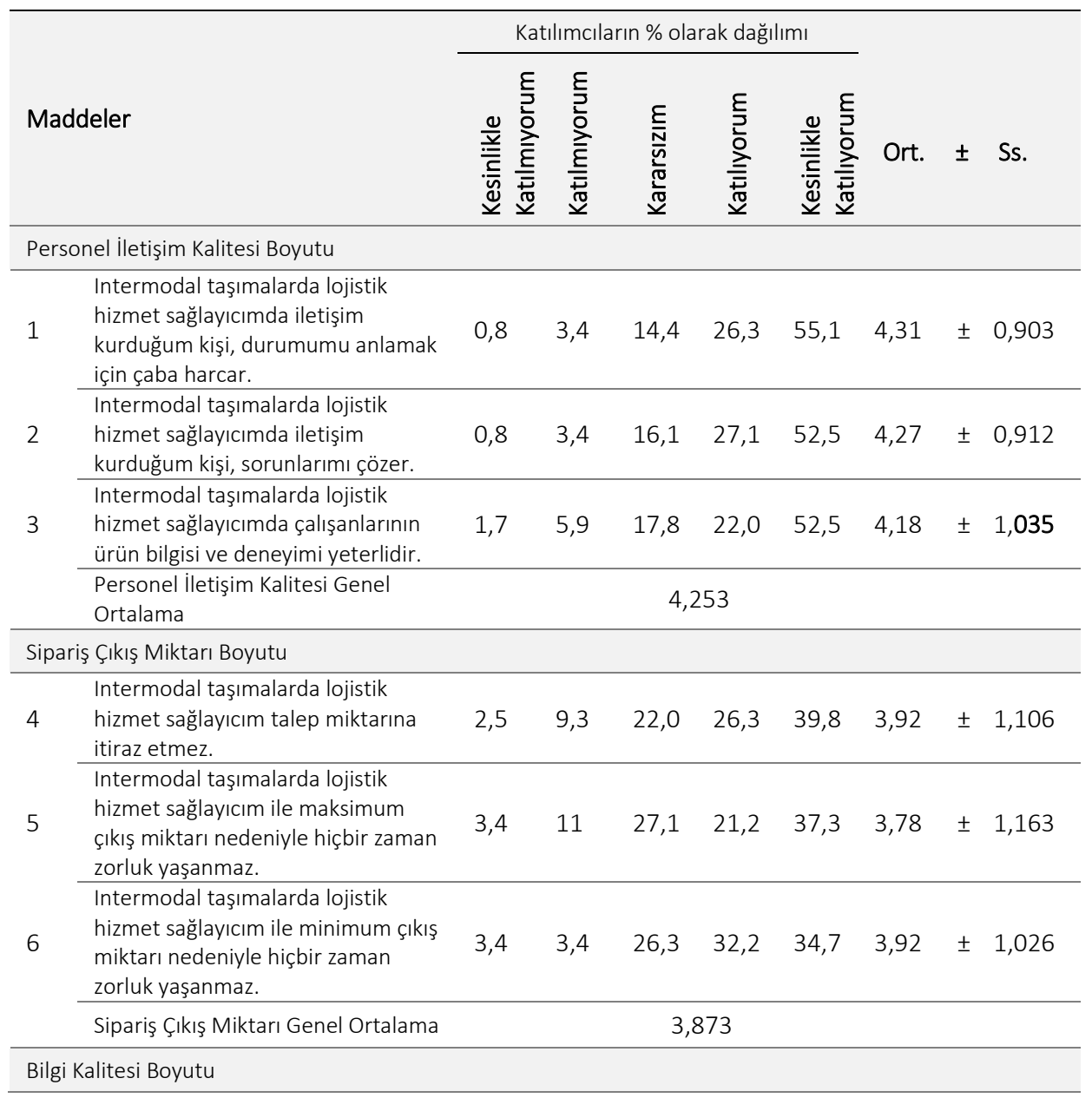




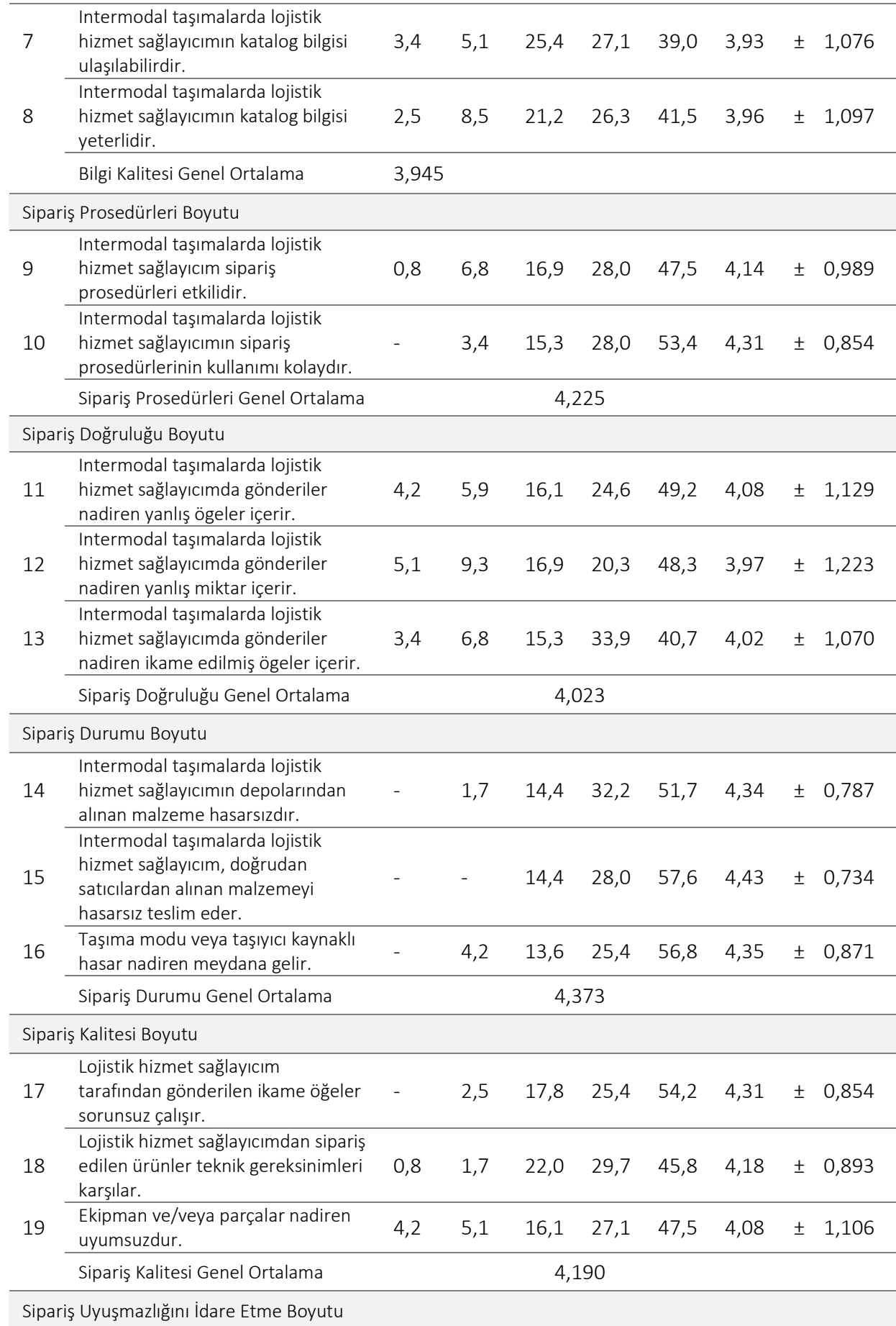




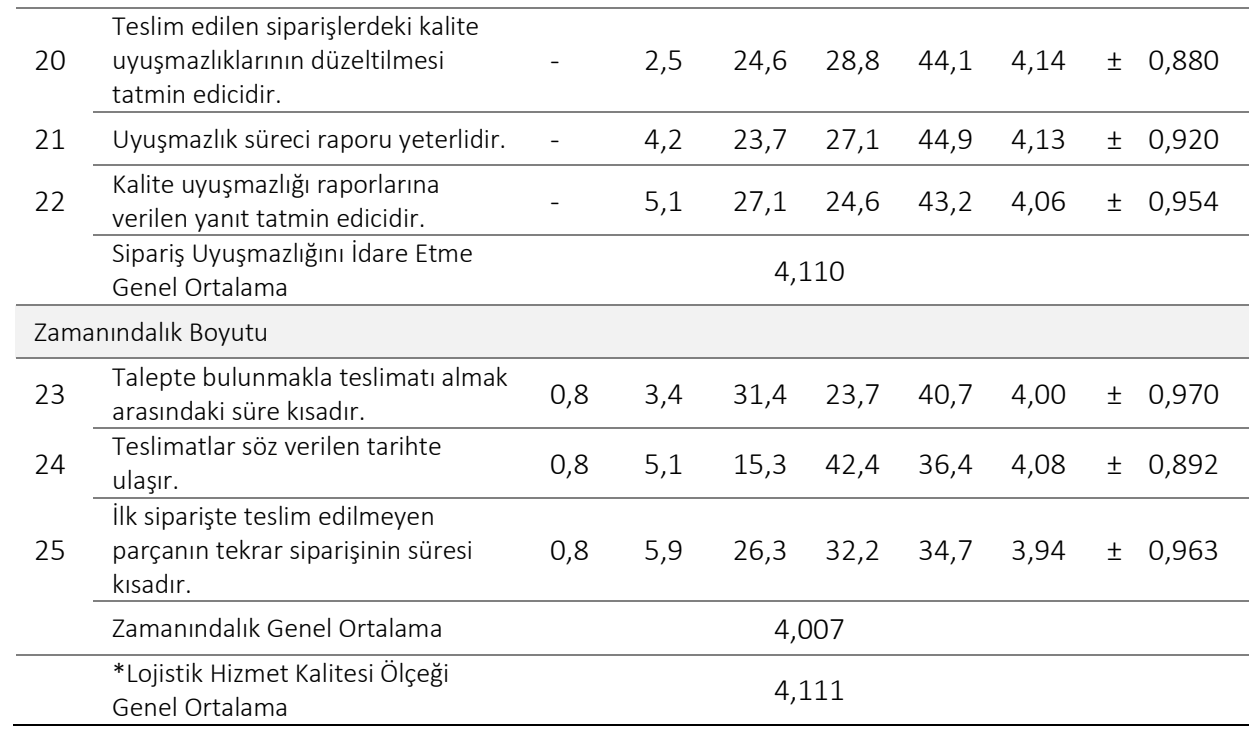

Personel iletişim kalitesi boyutu genel ortalama değeri 4,253, sipariş çıkış miktarı değeri 3,873, bilgi kalitesi genel ortalama değeri 3,945, sipariş prosedürleri genel ortalama değeri 4,225, sipariş doğruluğu değeri 4,023, sipariş durumu değeri 4,373, sipariş kalitesi boyu değeri 4,190, sipariş uyuşmazlığını idare etme değeri 4,110 ve zamanındalık değeri 4,007 olarak elde edilmiştir. Lojistik hizmet kalitesi ölçeği genel ortalama değeri ise 4,111 olarak elde edilmiştir.

Tablo 14. Müşteri güveni ölçeği boyutuna yönelik sıklık dağıım analizi

\begin{tabular}{|c|c|c|c|c|c|c|c|c|c|}
\hline \multirow{2}{*}{\multicolumn{2}{|c|}{ Maddeler }} & \multicolumn{5}{|c|}{ Katılımcıların \% olarak dağılımı } & \multirow[b]{2}{*}{ Ort. } & \multirow[b]{2}{*}{ \pm} & \multirow[b]{2}{*}{ Ss. } \\
\hline & & 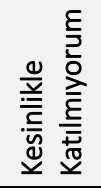 & 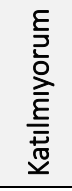 & 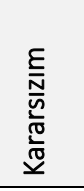 & 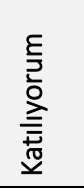 & 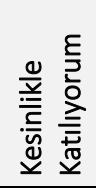 & & & \\
\hline 1 & $\begin{array}{l}\text { Lojistik hizmet sağlayıcım bana } \\
\text { güven verir. }\end{array}$ & - & 2,5 & 21,2 & 26,3 & 50,0 & 4,24 & \pm & 0,874 \\
\hline 2 & $\begin{array}{l}\text { Intermodal taşımalarda lojistik } \\
\text { hizmet sağlayııımın markası/isminin } \\
\text { bendeki imajı güvenilirdir. }\end{array}$ & - & 2,5 & 16,1 & 24,6 & 56,8 & 4,36 & \pm & 0,843 \\
\hline 3 & $\begin{array}{l}\text { Intermodal taşımalarda gelecekte } \\
\text { de lojistik hizmet sağlayııımın } \\
\text { müşterisi olmak isterim. }\end{array}$ & - & 2,5 & 16,9 & 29,7 & 50,8 & 4,29 & \pm & 0,838 \\
\hline 4 & $\begin{array}{l}\text { Intermodal taşımalarda lojistik } \\
\text { hizmet sağlayıcım güvenilirdir. }\end{array}$ & - & 0,8 & 13,6 & 28,8 & 56,8 & 4,42 & \pm & 0,755 \\
\hline
\end{tabular}


5 Intermodal taşımalarda lojistik

hizmet sağlayıcıma güvenim tamdır.

\section{$3,4 \quad 19,5 \quad 22,9 \quad 54,2 \quad 4,28 \quad \pm \quad 0,895$}

Müşteri güveni ölçeği genel ortalama değeri 4,318 olarak bulunmuştur. Çalışmada lojistik hizmet kalitesinin (bağımsız değişken) müşteri sadakati (bağımlı değişken) ve müşteri güveni (bağımlı değişken) etkisinin belirlenmesi amaçlı, regresyon analizi uygulanmıştır. Regresyon tahmin katsayılarının yorumlanabilir özellikte olması için t testi $\mathrm{H} 1, \mathrm{~F}$ testi $\mathrm{H} 1$ ve R2 belirginlik katsayısı değerinin yüksek olmasının yanı sıra; hata payı normal dağılımlı olmalı, otokorelasyon bulunmamalı, heteroskedasite olmamalı gibi varsayımların da sağlanması gerekmektedir. Ancak bu koşullar altında katsayılar güvenilir ve yorumlanabilir özellikte olacaktır. Varsayımların sağlanması için, Eviews 10.0 sürümü içinde bulunan Newey-West algoritması ile çözümler yapılarak varsayım sapmaları giderilmeye çalışılmıştır.

Tablo 15. Lojistik hizmet kalitesinin müşteri güvenine yönelik regresyon analizi sonuçları

\begin{tabular}{lllll}
\hline Bağımsız Değişken & $\boldsymbol{\beta}$ & Std. Hata & t istatistiği & P \\
\hline Sabit & 0.577614 & 0.106079 & 5.445135 & $0.0000^{*}$ \\
\hline $\begin{array}{l}\text { Lojistik Hizmet Kalitesi } \\
\text { R }=0.911029\end{array}$ & 0.070974 & 12.83611 & $0.0000^{*}$ \\
$\begin{array}{l}\text { Harvey test }(p)=0.118, \text { LM test }(p)=0.105 \\
\text { Jarque-Bera }(p)=0.244\end{array}$ & & & \\
\hline
\end{tabular}

Bağımlı Değişken: Müşteri Güveni * ${ }^{*} 0.05$ için anlamlı değişken

Tablo 15.'teki regresyon denkleminde, lojistik hizmet kalitesi müşteri güveni üzerinde pozitif yönde (olumlu yönde) anlamlı ilişkili çıkmıştır $(p<0.05)$. Lojistik hizmet kalitesi müşteri güvenini R2 =\%66,3 açıklama gücüne sahiptir. Lojistik hizmet kalitesi algısı 1 birim arttığında müşteri güveni algısı 0.911 birim artış gösterecektir. Böylece ana hipotez $\mathrm{H}_{1}$ sağlanmıştır.

Tablo 16. Lojistik hizmet kalitesi alt boyutlarının müşteri güvenine yönelik regresyon analizi

\begin{tabular}{lllll}
\hline Bağımsız Değişken & $\boldsymbol{\beta}$ & Std. Hata & t istatistiği & $\mathrm{P}$ \\
\hline Sabit & 0.721400 & 0.153567 & 4.697622 & $0.0000^{*}$ \\
\hline Personel İletişim Kalitesi & 0.264313 & 0.091616 & 2.885012 & $0.0047^{*}$ \\
\hline Sipariş Teslim Miktarı & 0.128694 & 0.069215 & 1.859336 & 0.0656 \\
\hline Bilgi Kalitesi & 0.421954 & 0.104659 & 4.031688 & $0.0001^{*}$ \\
\hline Sipariş Prosedürleri & 0.368868 & 0.076929 & 4.794899 & $0.0000^{*}$ \\
\hline Sipariş Doğruluğu & 0.346759 & 0.087683 & 3.954691 & 0.0001 \\
\hline
\end{tabular}




\begin{tabular}{lllll}
\hline Sipariş Durumu & 0.277283 & 0.307165 & 0.902719 & 0.3686 \\
\hline Sipariş Kalitesi & 0.307627 & 0.077060 & 3.992025 & $0.0001^{*}$ \\
\hline Sipariş Uyuşmazlığı Yönetimi & 0.213017 & 0.047151 & 4.517785 & 0.0000 \\
\hline Zamanındalık & 0.218590 & 0.080094 & 2.729152 & $0.0074^{*}$ \\
\hline $\begin{array}{l}\text { R2 }=0.733 \quad \text { Fhesap }=21.16 \text { Fanlamlılık }=0.000, \\
\text { Harvey test }(p)=0.129, \text { LM test }(p)=0.136\end{array}$ & & & \\
Jarque-Bera $(p)=0.251$ & & & \\
\hline
\end{tabular}

$$
\text { Bağımlı Değişken: Müşteri Güveni * *0.05 için anlamlı değişken }
$$

Tablo 16.'daki regresyon denkleminde, lojistik hizmet kalitesi alt boyutları sipariş çıkış miktarı ve sipariş durumu anlamlı ilişkili çıkmamıştır ( $p>0.05)$. Bu iki alt boyut dışında kalanlar müşteri güveni üzerinde pozitif yönde (olumlu yönde) anlamlı ilişkili çıkmıştır $(p<0.05)$. Lojistik hizmet kalitesi alt boyutları müşteri güvenini R2 = \%73,3 açıklama gücüne sahiptir.

Personel iletişim kalitesi algısı 1 birim arttığında müşteri güveni algısı 0.721 birim artış gösterecektir. Bilgi kalitesi algısı 1 birim arttığında müşteri güveni algısı 0.421 birim artış gösterecektir. Sipariş prosedürleri algısı 1 birim arttığında müşteri güveni algısı 0.368 birim artış gösterecektir. Sipariş doğruluğu algısı 1 birim arttığında müşteri güveni algısı 0.346 birim artış gösterecektir. Sipariş kalitesi algısı 1 birim arttığında müşteri güveni algısı 0.307 birim artış gösterecektir. Sipariş uyuşmazlığını idare etme algısı 1 birim arttığında müşteri güveni algısı 0.213 birim artış gösterecektir. Zamanındalık algısı 1 birim arttığında müşteri güveni algısı 0.218 birim artış gösterecektir. Sipariş çıkış miktarı ve sipariş durumu istatistik anlamlı çıkmamıştır. Böylece alt hipotez H1a kısmen sağlanmıştır.

\section{Tartışma ve Sonuç}

Ülkemizde ve dünyada artan yeşil lojistik akımı, karbon ayak izi akımı ve bunların etkisi ile birlikte CO2 salınımının azaltılması konusunda yapılan çalışmalar lojistik merkezlerin oluşumunu desteklemiş ve bu merkezlerin altyapıları modlar arası geçişe uygun olacak şekilde planlanmıştır. Lojistik köy olarak da adlandırılan bu merkezlerde kap değişimi yapılmadan uygun taşıma aracına elleçleme imkanı veren intermodal taşımalar git gide popülaritesini ve kullanımını arttırmıştır. Denizyolu ve demiryolu taşımalarında aynı anda çoklu yük taşımalarının yapılabilmesi sonucunda hem daha uygun fiyatlı bir taşıma organizasyonu yapılabilecek hem de sürdürülebilir bir dünya için tercih sebebi olarak bu taşıma türleri daha da ön plana çıkacaktır. Daha sürdürülebilir taşıma organizasyonları için çok modlu taşımaların desteğini almak artık bir zorunluluk haline gelmiştir (Küçük vd., 2017).

Çalışmada lojistik hizmet kalitesinin müşteri güvenine etkisinin istatistik olarak anlamlı olup olmadığı araştırılmıştır. Yapılan regresyon analizinin değerlendirilmesi sonucunda 
lojistik hizmet kalitesi genel skorunun müşteri güveni üzerinde yüksek açıklama gücü etkisiyle pozitif yönde yani olumlu anlamda etkisi vardır. Oluşturulan alt hipotezlerde lojistik hizmet kaliyetisin dokuz alt boyutunu oluşturan personel iletişim kalitesi, sipariş çıkış miktarı, bilgi kalitesi, sipariş prosedürleri, sipariş doğruluğu, sipariş durumu,sipariş kalitesi, sipariş uyuşmazlığını idare etme, zamanındalık alt boyutları ile müşteri güveni arasında anlamlı bir farklılık olup olmadığı araştırılmıştır. Lojistik hizmet kalitesine ait dokuz alt boyuttan sipariş çıkış miktarı ve sipariş durumu anlamlı ilişkili çıkmamıştır. Bunlar haricinde kalan yedi alt boyut için gerçekleşen her olumlu gelişme müşteri güvenine de aynı şekilde olumlu yönde yansıyacaktır. Yıldız (2020) tarafından yapısal eşitlik modeli kullanılarak daha önce yapılan çalışmada e-ticaret sektöründe faaliyet gösteren işletmelerin lojistik hizmet kalitesinin müşteri güvenine etkisi araştırılmıştır. Lojistik hizmet kalitesinin memnuniyet ve güveni pozitif yönde etkilediği ve sadakati anlamlı bir şekilde etkilemediği sonucu elde edilmiştir. Analiz sonucu elde edilen bulgular Yıldız (2020)'ın çalışmasını destekler niteliktedir. Çalışmada özellikle sermaye yapısı özelliği dikkate alındığında yerli-yabancı ortaklığı olan firmalar için lojistik hizmet kalitesinin, sipariş durumu alt boyutuna anlamlı derecede etki ettiği görülmektedir. Yabancı sermaye sahibi firmaların kontrollü olma ve garanticilik güdüsüyle yükün kondisyonu, hasarsızlığı ve eksiksizliği bu firmaların tercih edilmesinde önemli bir etken olarak değerlendirilebilir (Gümüş, 2013).

Bu çalışmanın en önemli kısıtı İstanbul'da intermodal taşımacılık hizmeti veren bir firmanın müşterileri olmasıdır. Zaman ve maliyet kısıtı nedeniyle anket soruları Likert Ölçeği'ne göre hazırlanmış ve katılımcıların sorulara samimi ve doğru cevap verdikleri varsayılmıştır. Bundan sonraki çalışmalarda intermodal taşımacılık hizmetlerinin lojistik hizmet kalitesi Servqual ölçeği kullanılarak analiz edilebilir ve sonuçları bu çalışmayla karşılaştırılabilir.

\section{Makalenin Araştırma ve Etik Beyanı Bilgileri}

Yazar Çıkar Çatışması Beyanı

Yazar Katkı Oranı

Beyanı

Etik Kurul Onay Belgesi
Araştırmaya konu olan durum ve olgular ile yazarlar arasında herhangi bir çıkar çatışması bulunmamaktadır.

Oktay Güngör \%60 ve Aynur Acer \%40

Araştırmanın etik kurul onayı 07/09/2021 tarihinde İstanbul Arel Üniversitesi Etik Kurulu'nun 2021/12 No2lu kararı ile elde edilmiştir. 


\section{Kaynakça}

Adebayo, I. T. (2017). An Evaluation of the Impact of Business-to-Customer (B2C) Logistics Service Quality (LSQ) on Customer Satisfaction in Nigeria. IOSR Journal of Business and Management, 19(4), 111-115.

Atılgan, K. Ö. \& Alhussein, H. (2021). Internet Sitesi Tasarımının Müşteri Güveni, Müşteri Memnuniyeti ve Satın Alma Niyetine Etkisi. Çankırı Karatekin Üniversitesi Iktisadi ve Idari Bilimler Fakültesi Dergisi, 11(1), 351-375.

Bakan, İ., \& Şekkeli, Ü. Z. H. (2018). Lojistik Hizmet Kalitesinin Müşteri Sadakati Üzerine Etkisi: Kahramanmaraş Ilinde Bir Alan Çalışması. 54. TURAN: Stratejik Arastirmalar Merkezi, 10(40), 123.

Bienstock, C. C., Mentzer, J.T. \& Bird, M. (1997). Measuring Physical Distribution Service Quality. Journal of Academy of Marketing Science, 25(1), 31-44.

Craig, A., Blanco, E., \& Sheffi, Y. (2013). Estimating the CO2 Intensity of Intermodal Freight Transportation. Transportation Research Part D: Transport and Environment, 22, 49-53.

Çekerol, G., \& Nalçakan, M. (2011). Lojistik Sektörü İçerisinde Türkiye Demiryolu Yurtiçi Yük Taşıma Talebinin Ridge Regresyonla Analizi. Marmara Üniversitesi İktisadi ve idari Bilimler Dergisi, 31(2), 321-344.

Doney, P. M., \& Cannon, J. P. (1997). An Examination of the Nature of Trust in BuyerSeller Relationships. Journal of Marketing, 61, 35-51.

Farahani, R. Z., Rezapour, S., \& Kardar, L. (2011). Logistics Operations and Management: Concepts and Models. Elsevier.

Fawcett, S. E., \& Cooper, M. B. (1998). Logistics Performance Measurement and Customer Success. Industrial Marketing Management, 27(4), 341-357.

Flint, D. J., \& Gammelgaard, B. (2007). Value and Customer Service Management. John T. Mentzer, Matthew B. Myers, \& Theodore P. Stank (Ed.) içinde, Handbook of Global Supply Chain Management. California: Sage Publications.

Grönroos, C. (1984). A Service Quality Model and Its Marketing Implications. European Journal of Marketing, 18(4), 36- 44.

Gümüş, S. (2013). Lojistik Sektörünün Türk Ekonomisine Katkıları ve Bir Araştıma. Business \& Management Studies: An International Journal, 1(3), 302-324.

Hacıefendioğlu, Ş., \& Çolular, N, (2008). Illişkisel Pazarlamada Güven Unsuru ve Otel İşletmelerinde Uygulama. Kocaeli Üniversitesi Sosyal Bilimler Enstitüsü Dergisi, 16(2), 107-126.

Hallikainen, H., \& Laukkanen, T. (2018). National Culture and Consumer Trust in ecommerce. International Journal of Information Management, 38(1), 97-106. 
Hatipoğlu, S., \& Işık, E.S. (2015). Havayolu Ulaşımında Hizmet Kalitesinin Ölçülmesi: İç Hatlarda Bir Uygulama. Kocaeli Üniversitesi Sosyal Bilimler Dergisi, 12(2), 293312.

Hoffman, K. D., \& Bateson, J. E. (1997). Essentials of Service Marketing. Florida.

İlhan, K. (2021). İnternet Üzerinden Alişverişlerde Elektronik Hizmet Kalitesi ve Lojistik Hizmet Kalitesinin Müşteri Memnuniyeti ve Sadakatine Etkisi. Journal of International Social Research, 14(80).

Karadeniz, M., \& Işık, M. (2014). Lojistik Hizmet Kalitesi ile Müşteri Memnuniyeti Ilişkisi: E-ticaret Üzerine Bir Araştırma. Istanbul Journal of Social Sciences, Summer, (7), $1-24$.

Kasapoğlu, L., \& Cerit, A. G. (2011). Türkiye'de Intermodal Konteyner Taşımacılığında Demiryolu Ulaştırma Potansiyelinin Analizi. Dokuz Eylül Üniversitesi Denizcilik Fakültesi Dergisi, 3(1), 59-72.

Kılcı, H. (2017). Taşımacılık Faaliyetlerinin Rekabet Üstünlüğü Oluşturmada İşletmecilikte Yeri ve Önemi: Türkiye Örneği ve Türkiye'de Taşımacılığın Gelişimi. Balkan Sosyal Bilimler Dergisi, (ICOMEP 2017 özel sayısı), 74-86.

Kim, H. W., Xu, Y., \& Koh, J. (2004). A Comparison of Online Trust Building Factors between Potential Customers and Repeat Customers. Journal of the Association for Information Systems, 5(10), 392-420.

Kordnejad, B. (2014). Intermodal Transport Cost Model and Intermodal Distribution in Urban Freight. Procedia - Social and Behavioral Sciences, 125, 358-372.

Korucuk, S. (2018). İmalat İşletmelerinde Lojistik Hizmet Kalitesinin İşletme Verimliliğine Etkisinin Lojistik Regresyon Analizi ile Belirlenmesi: Erzincan Ili Örneği. Erzincan Üniversitesi Sosyal Bilimler Enstitüsü Dergisi, 11(2), 30-43.

Küçük, O., Yeşilyurt, E., \& Kartal, Ö. (2017). Lojistik Köy Performans Faktörlerinin Önem Düzeyinin Belirlenmesi: Kastamonu Örneği. The International New Issues In Social Sciences, 4(4), 37-42.

Macharis, C. \& Bontekoning, Y.M. (2004). Opportunities for OR in Intermodal Freight Transport Research: A Review. European Journal of Operational Research, 400416

Maltz, A., \& Maltz, E. (1998). Customer Service in The Distributor Channel Empirical Findings. Journal of Business Logistics, 19(2), 103.

Martinez, P., \& Del Bosque, I. R. (2013). The Role of Consumer Identification on the Effects of Corporate Social Responsibility on Consumer Behaviour in The Spanish Hotel Industry. Revista de Análisis Turístico, 22(5), 896-917. 
Massaroni, E., Cozzolino, A., \& Wankowicz, E. (2016). Sustainability Reporting of Logistics Service Providers in Europe. International Journal of Environment and Health, 8(1), 38-58.

Mentzer, J. T., Flint, D. J., \& Hult, T. M. (2001). Logistics Service Quality as a SegmentCustomized Process. Journal of Marketing, 65(4), 82-104.

Mentzer, J. T., Flint, D. J., \& Kent, J. L. (1999). Developing a Logistics Service Quality Scale. Journal of Business Logistics, 20(1), 9-32.

Mentzer, J. T., Gomes, R., \& Krapfel, R. E. (1989). Physical Distribution Service: A Fundamental Marketing Concept?. Journal of the Academy of Marketing Science, 17(1), 53-62.

Mosavi, S. A., \& Ghaedi, M. (2012). A Survey on the Relationship between Trust, Customer Loyalty, Commitment and Repurchase Intention. African Journal of Business Management, 6(36), 10089-10098.

Murphy, Jr. P. R., \& Knemeyer, A. M. (2016). Güncel Lojistik. (Ed. F. Yenercan ve Ş. Demiroğlu, Çev.). Ankara: Nobel Akademik Yayıncılık, 115-116.

Oflaç, B. S., \& Uyguç, B. B. (2017). Intermodal Taşımacılık: Tercih Nedenleri ve AvrupaTürkiye Arasındaki Problemler. Business and Management Studies: An International Journal, 5(3), 842-858.

Orel, F. D., Nakıboğlu, G., \& Oygür, L. (2012). Lojistik Hizmetlerde Algılanan Hizmet Kalitesi Boyutlarının Müşteri Tatmini Üzerindeki Etkileri. Finans Politik ve Ekonomik Yorumlar, (563), 41-41.

Oskaybaş, K., Dursun, T., \& Yener, D. (2014). Online Alışverişte Tüketicilerin Tercihlerini Etkileyen Unsurların Belirlenmesi. Marmara Üniversitesi I.I.B. Dergisi, 36(1), 119135.

Parasuraman, A., Zeithaml Valarie A. \& Berry Leonard L. (1985). A Conceptual Model of Service Quality and Implications for Further Research. Journal of Marketing, 49, 41-50

Raimondo, M. A. (2000). The Measurement of Trust in Marketing Studies: A Review of Models and Methodologies. 16th IMP-conference. Bath-UK.

Rinehart, L. M., Cooper, M. B., \& Wagenheim, G. D. (1989). Furthering the Integration of Marketing and Logistics Through Customer Service in the Channel. Journal of the Academy of Marketing Science, 17(1), 63-71.

Rodrigue, J., Comtois, C., \& Slack, B. (2017). The Geography of Transport Systems. New York: Routledge, ss. 143-176.

Rushton, A., Croucher, P., \& Baker, P. (2010). The Handbook of Logistics and Distribution Management (4. b.). London: Kogan Page Limited. 
Saraçoğlu, T. (2013). İşletmelerde Kurumsal Sosyal Sorumluluk Uygulamalarını Müşteri Güveni, Müşteri Bağlılığı ve Firma Imajı Üzerindeki Etkileri: Otel İşletmelerinde Bir Uygulama. Aydın: Adnan Menderes Üniversitesi Sosyal Bilimler Enstitüsü Yayınlanmamış Doktora Tezi.

Seçilmiş, C., Kaşlı, M., Kılıçlar, A.V., \& Sarı, Y. (2001). Demiryolu Hizmetlerindeki Kalitenin Ödenen Ücret Açısından Müşteri Tatminine Etkisi. Ege Akademik Bakış, 11(4), 573-586.

Siau, K., \& Shen, Z. (2003). Building Customer Trust in Mobile Commerce. Communications of The ACM, 46(4), 91-94.

Suhartanto, D., Helmi Ali, M., Tan, K. H., Sjahroeddin, F., \& Kusdibyo, L. (2019). Loyalty toward Online Food Delivery Service: The Role of E-Service Quality and Food Quality. Journal of Foodservice Business Research, 22(1), 81-97.

Toygar, A. (2018). Algılanan Hizmet Kalitesinde E-lojistik Uygulamalarının Rolü: Lojistik işletmeleri Üzerine Bir Araştırma. Balıkesir: Bandırm Onyedi Eylül Üniversitesi, Sosyal Bilimler Enstitüsü Yüksek Lisans Tezi.

Turban, E., Outland, J., King, D., Lee, J. K., Liang, T. P., \& Turban, D. C. (2018). A Managerial and Social Networks Perspective. New York: Springer International Publishing.

Uzel, E., \& Tuna, O. (2014). The effect of Logistics Service Quality on Past Purchase Behavioral Intention in On-line Shopping. Journal of Management Marketing and Logistics, 1(3), 241-258.

Yangınlar, G., \& Tuna, F. (2020). Havayolu Taşımacılığında Hizmet Kalitesinin Kurumsal İmaj, Müşteri Memnuniyeti ve Müşteri Sadakati Üzerindeki Etkisi. İşletme Araştırmaları Dergisi, 12(1), 173-187.

Yıldız, B. (2020). E-ticaret Lojistik Hizmet Kalitesinin Güven, Memnuniyet ve Sadakat Üzerindeki Etkisi. Giresun Üniversitesi Iktisadi ve Idari Bilimler Dergisi, 6(1), 3759.

Yıldız, E. (2018). Effects of Logistics Service Quality on Behavioral Intention: An Application on Electronic Service Customers. Icpess 2018 Proceedings Volume 2: Ecomonic Studies, 43. 


\title{
The Effect of Logistics Service Quality on Customer Trust and an Application in Intermodal Transport Services
}

\author{
Extented Abstract
}

\begin{abstract}
Purpose and Significance
Transportation activity being one of the most important logistics activities, is the process of physical flow of raw materials, intermediate products and materials within the relevant enterprise or It is the process of physically sending final products from a business to distribution channels. It is very important that these needed products are delivered to the right people undamaged. Delivering this need at the right time, at the right place, in the right quantity, under the right conditions and undamaged, is an activity that adds value to transportation and the manufacturer (KılCI, 2017).

Transportation is a service that has started since the beginning of human history. This activity, which was initially carried out with different types of unimodal transport such as road, air, sea, rail and pipeline, it has become nowadays more differentiated and diversified with the effect of cost and environmentalist activities. The geographical infrastructure and product characteristics of the countries have allowed the development of different types of transportation and multimodal transportation has begun to be used as an alternative. In all multi-transports, more than one type of transportation is used together, creating a cost advantage and improving services by offering a safer and greener transportation activity. Intermodal transport is only one of these multimodal transport types. Macharis and Bontekoning (2004) define intermodal transport as "the combination of at least two modes of transport in a single transport chain, in which most of the route is traversed by rail, inland waterway or ocean-going vessels without the change of transport container for goods". He underlines that road transport is very rare in intermodal transport, and it is generally used for short distances especially in the initial and final transportation of products.

The structure of the goods and the transfer speeds at the terminals affect the service quality of the logistics service providers, and as a result of this, the tendency towards intermodal transports is increasing compared to unimodal transports (Oflaç and Uyguç, 2017). With the integration of intermodal transportation services, it is aimed to reduce and facilitate the handling activities to be carried out during the transfer of cargo from one type of transportation to another, and to ensure efficiency in this sense (Kasapoğlu and Cerit, 2011). The growth of international trade in recent years has led to an increase in the trend towards
\end{abstract}


the use of intermodal transport and, as a result, an increase in research on this topic. These researches show us that intermodal transportation has a positive effect on the transportation economy with its effect on efficiency and transportation costs. Compared to a single-mode mode of transport, it saves $20 \%$ on transport costs and $63 \%$ train loading space utilization reaches equilibrium (Kordnejad, 2014). An intermodal system can minimize the environmental impact in terms of $\mathrm{CO} 2$ emissions by up to $57 \%$ compared to a single mode system (Craig vd., 2013).

In addition to the cost minimization efforts of the enterprises, this type of transportation has found itself in a continuous development process with the reflection of the $\mathrm{CO} 2$ emission, increased sensitivity to environmental movements, the effort to carry out activities based on sustainable and green logistics, on intermodal transportation (Rodrigue vd., 2017). This development has brought with it innovative changes and operational diversity, and has assigned some duties to companies providing logistics services in this field. It has now become a necessity for companies that carry out intermodal transportation activities to become businesses that give confidence to their customers by perfecting the services offered in order to make these services sustainable and permanent. For this reason, the effect of logistics service quality on customer trust in intermodal transportation activities was deemed worthy of research in this study. This study consists of four parts after the introduction. In the first part, the concepts of logistics service quality and customer trust, which constitute the conceptual framework, are mentioned. The second part of the study consists of a literature review. In the third part, information is given about the method of the research and the hypotheses. In the last part, the obtained data were analyzed and interpreted.

\section{Method}

In the study, the effect of logistics service quality on customer trust in intermodal transportation services was investigated and the data obtained were analyzed with the regression model. In order for the regression estimation coefficients to be interpretable, the t test $\mathrm{H} 1, \mathrm{~F}$ test $\mathrm{H} 1$ and $\mathrm{R} 2$ significance coefficient values must be high, as well as other assumptions must be met. The data were obtained by contacting the customers of a multinational company operating in the intermodal transportation sector in Turkey through a survey. In the study in which the convenience sampling method was applied, the answers of 118 users constitute the data set. The surveys were conducted online between 05.03.2021 and 16.05.2021. IBM SPSS 25.0 package program and Eviews 10.0 version were used in the evaluation of the data and the results were interpreted.

The survey part consists of three parts. In the first part, questions about the demographic characteristics of the employees and company information were included. In the second part, the logistics service quality scale (LQS), which was created by Mentzer, Flint and Kent 
in 1999 and developed with the contributions of Mentzer, Flint and Hult in 2001, consisting of nine sub-dimensions and a total of 25 statements was used. The sub-dimensions of the LQS scale, which consists of 25 expressions, are listed as follows: timeliness, inter-employee relationship quality, order status, order procedures, order dispute management, order delivery quantity, order quality, order accuracy, information quality. In the last part of the questionnaire, a five-item scale developed by Mosavi and Ghaedi (2012) was included. The scales used include statements arranged in a five-point likert format. In the study, the reliability of the scales was tested before the analysis. The Cronbach Alpha test, which is one of the most used methods in reliability analysis, was used and the Cronbach Alpha value was obtained as 0.961 . If this value is more than 0.70 , it indicates that the scale is reliable.

The main hypothesis of the research is that the effect of logistics service quality on customer trust is statistically significant. The sub-hypotheses were established in the direction that each of the sub-dimensions ( timeliness, inter-employee relationship quality, order status, order procedures, order dispute management, order delivery quantity, order quality, order accuracy and information quality) constituting the logistics service quality has a statistically significant effect on customer trust, one by one.

\section{Findings}

When the data obtained from 118 users were evaluated, the following information was obtained about the companies. When the information about the number of personnel working in the company is evaluated, $23.7 \%$ of them are $11-25$ people, $15.3 \%$ of them are 500 people and above, $12.7 \%$ are $1-10$ people, $12.7 \%$ are $50-99$ people. It was observed that $11.9 \%$ of the personnel consisted of 26-49 personnel, $11.9 \%$ of them were between $100-249$ personnel and $11.9 \%$ of them were in the range of $250-499$ personnel. When the capital structure of the companies participating in the survey is evaluated, it has been found that $63.6 \%$ of the companies have $100 \%$ domestic, $21.2 \%$ of them are domestic-foreign partnerships and $15.3 \%$ are companies that have $100 \%$ foreign capital. $37.3 \%$ of the users who participated in the survey work in companies that provide services in transportation, customs clearance and all other logistics activities. When the share of logistics in the total expenditures of the companies where the users work is evaluated, it has been determined that $31.4 \%$ is between $11-25 \%$. $32.2 \%$ of the companies that users work with are railway containers and $23.7 \%$ are railway containers+RO-RO as intermodal transportation type. $35.6 \%$ of the companies participating in the survey have been doing intermodal transportation activities for more than 10 years. Finally, the share of intermodal transportation in the logistics activities of $40.7 \%$ of the companies where the participants work was less than $10 \%$. When the answers given by the users participating in the survey to all the statements in the LQS scale are evaluated, there is an average of 4,11 satisfaction. Similarly, when the answers given to the statements in the customer trust scale are 
evaluated, the overall average is 4,32. In the obtained regression equation, logistics service quality was found to be positively (positively) significantly correlated with customer trust. Logistics service quality has the power to explain customer confidence $66.3 \%$. When the perception of logistics service quality increases by one unit, the perception of customer trust will increase by 0.911 units.

\section{Discussion and Conclusions}

As a result of simultaneous multi-load transportation in sea and rail transportation, a more affordable transportation organization can be made and these transportation types will come to the fore as a reason for preference for a sustainable world. In the study investigating whether the effect of logistics service quality on customer trust in intermodal transportation is statistically significant or not, as a result of the evaluation of regression analysis, it has been found that the overall score of logistics service quality has a high explanatory power on customer trust. on the other hand, there was no statistically significant relationship between the order output quantity and order status, which are the nine sub-dimensions of logistics service quality, and customer confidence. In addition, especially considering the capital structure variable, it is seen that the logistics service quality for companies with domesticforeign partnerships has a significant effect on the order status sub-dimension. 
